\title{
PENGARUH IKLIMTERHADAP MUSIM TANAM RUMPUT LAUT, Kappaphycus alvarezii DI TELUK GERUPUK KABUPATEN LOMBOK TENGAH, NUSA TENGGARA BARAT
}

\author{
I Nyoman Radiarta*), Erlania*), dan Rusman**) \\ *) Pusat Penelitian dan Pengembangan Perikanan Budidaya \\ Jl. Ragunan 20, Pasar Minggu, Jakarta Selatan 12540 \\ E-mail: radiarta@yahoo.com \\ *) Balai Budidaya Laut \\ Po Box I Sekotong Barat, Desa Gili Genting Sekotong Barat, Kabupaten Lombok Barat
}

(Naskah diterima: 26 Juni 2013; Disetujui publikasi: 4 September 2013)

\begin{abstract}
ABSTRAK
Rumput laut merupakan komoditas unggulan perikanan budidaya di Indonesia. Pengembangan kawasan budidaya rumput laut dapat dipengaruhi oleh kondisi lingkungan biofisik perairan dan kondisi iklim. Salah satu faktor pembatas dalam budidaya rumput laut adalah musim tanam. Tujuan dari penelitian ini adalah untuk mengkaji pola musim tanam rumput laut yang dihubungkan dengan perubahan iklim yang terjadi di Teluk Gerupuk Kabupaten Lombok Tengah, Nusa Tenggara Barat. Data primer yang dikumpulkan dalam penelitian ini meliputi data keragaan budidaya rumput laut dan pola musim tanam. Data sekunder diperoleh dari berbagai instansi terkait meliputi Badan Meteorologi Klimatologi dan Geofisika, NOAA Center for Weather and Climate Prediction, dan Dinas Kelautan dan Perikanan. Data yang terkumpul dianalisis dan dibahas secara deskriptif yang disertai dengan gambar. Hasil dari penelitian ini menunjukkan bahwa produktivitas lahan pengembangan rumput laut sangat dipengaruhi oleh kondisi iklim. Adanya perubahan iklim baik nasional maupun global (El Niño dan La Niña) sangat memengaruhi pola musim tanam rumput laut di Teluk Gerupuk. Musim tanam produktif umumnya terjadi pada bulan di mana curah hujan rendah (musim kemarau) dan suhu udara juga rendah $\left(24^{\circ} \mathrm{C}-27^{\circ} \mathrm{C}\right)$.
\end{abstract}

KATA KUNCI: perubahan iklim, musim tanam, rumput laut, Lombok Tengah

ABSTRACT: Impact of climate on seaweed, Kappaphycus alvarezii planting periods in Gerupuk Bay, Central Lombok Regency, West Nusa Tenggara. By: I Nyoman Radiarta, Erlania, and Rusman

Seaweed is an important aquaculture commodity in Indonesia. Seaweed cultivation can be affected by environmental and climate conditions. One of the limiting factors in seaweed cultivation is the planting/growing periods. The purpose of this study was to examine seaweed planting/growing periods associated with climate change that occurred in Gerupuk Bay Central Lombok Regency, West Nusa Tenggara. Primary data were used in this study including variability seaweed cultivation and planting periods. Secondary data were obtained from various agencies such as Meterology Climatology and Geophysics Agency (BMKG), NOAA Center for Weather and Climate Prediction, and Local Agency for Marine Affair and Fisheries. All data were then analyzed and discussed descriptively, in order to observe the connectivity among them related with the climate condition. The results show that productivity of seaweed cultivation was strongly influenced by climatic conditions. Climate change, both nationally and 
globally (EI Niño and La Niña) was influenced the seaweed planting/growing periods in Gerupuk Bay. Productive planting/growing periods generally occurs in low rainfall (dry season) and also low temperature $\left(24^{\circ} \mathrm{C}-27^{\circ} \mathrm{C}\right)$.

\section{KEYWORDS: climate change, planting periods, seaweed, Central Lombok}

\section{PENDAHULUAN}

Rumput laut merupakan komoditas unggulan perikanan budidaya di Indonesia. Melalui program minapolitan dan industrialisasi Kementerian Kelautan dan Perikanan (KKP), komoditas ini merupakan satu dari empat komoditas unggulan pengembangan perikanan budidaya di tahun 2012, ketiga komoditas lainnya adalah udang, ikan patin, dan ikan bandeng. Produksi rumput laut di Indonesia menunjukkan peningkatan yang sangat signifikan, yaitu dari sekitar 205 ribu ton di tahun 2000 menjadi sekitar 3,9 juta ton di tahun 2012 (FAO Fisheries and Aquaculture Department, 2012). Upaya peningkatan produksi tersebut terus dilakukan melalui identifikasi kawasan potensial pengembangan di setiap kabupaten/provinsi. Selain konsep minapolitan dan industrialisasi, prinsip pembangunan ekonomi biru (blue economy) merupakan konsep pembangunan kelautan dan perikanan yang belakangan ini menjadi perhatian KKP. Melalui konsep ini diharapkan dapat memperkuat ketahanan pangan dan ekonomi demi mencapai pertumbuhan yang berkelanjutan. Budidaya rumput laut dapat dijadikan sebagai aktivitas dalam penerapan konsep ekonomi biru karena: (1) Mengintegrasikan antara sosial, ekonomi, dan lingkungan; (2) Pengembangannya berbasis kawasan; (3) Sistem produksi bersih efisien bebas pencemaran, tidak merusak lingkungan, dan bermanfaat bagi seluruh masyarakat; serta (4) Berkelanjutan dengan cara menjaga keseimbangan antara pemanfaatan sumberdaya alam dan pelestarian lingkungan dan antara produksi dan konsumsi (Anonim, 2012a).

Pengembangan kawasan budidaya rumput laut dapat dipengaruhi oleh kondisi lingkungan biofisik perairan dan kondisi iklim. Kajian kelayakan lahan rumput laut yang telah banyak dilakukan baik dianalisis secara manual ataupun spasial (Radiarta et al., 2012), belum sepenuhnya dapat dijadikan jaminan keberhasilan budidaya rumput laut pada suatu kawasan. Hal ini disebabkan kondisi perairan yang bersifat sangat dinamik, serta adanya pengaruh iklim yang belakangan ini sulit untuk diprediksi (anomali iklim). Kegagalan panen yang sering dialami oleh pembudidaya rumput laut banyak disebabkan oleh pengaruh gelombang besar yang menghancurkan media dan biota budidaya, serta adanya anomali dan iklim berupa curah hujan yang sangat tinggi ataupun musim panas yang berkelanjutan sehingga dapat berakibat pada munculnya penyakit (ice-ice) atau membusuknya rumput laut yang dibudidayakan (Santosa \& Nugraha, 2008). Berdasarkan kondisi tersebut, menunjukkan bahwa iklim menjadi salah satu faktor yang sangat penting diperhatikan dalam keberlanjutan usaha budidaya rumput laut.

Salah satu faktor pembatas dalam budidaya rumput laut adalah musim tanam. Hasil penelitian menunjukkan bahwa respons pertumbuhan rumput laut berbeda antar waktu dan musim dalam setahun (Pratiwi \& Ismail, 2004; Pong- Masak et al., 2009; Rusman, 2012). Pendekatan budidaya berdasarkan perubahan musim dan kondisi lingkungan perairan yang optimal bagi pertumbuhan rumput laut, diharapkan dapat menjadi acuan pengelolaan dan pemanfaatan lahan budidaya laut bagi peningkatan produksi rumput laut secara optimal dan produktif.

Kabupaten Lombok Tengah merupakan satu kabupaten kawasan pengembangan budidaya rumput laut baik melalui program nasional minapolitan maupun PIJAR (sapi, jagung, dan rumput laut; program Provinsi Nusa Tenggara Barat). Dua kawasan pengembangan utama yang telah ditentukan adalah Gerupuk dan Awang dengan total Iuasan potensi lahan yang ada sebesar 475 ha (Anonim, 2011a). Kebutuhan data dan informasi tentang karakteristik lahan pengembangan budidaya rumput laut di dua lokasi tersebut sangat diperlukan guna mendukung peningkatan produksi yang maksimal. Kajian yang dapat dilakukan baik berupa kajian potensi lahan yang memadukan antara kondisi biofisik perairan dan sosial kemasyarakatan, dan kondisi iklim yang berpengaruh terhadap lingkungan perairan. Tujuan dari penelitian ini adalah untuk mengkaji pola musim tanam rumput laut yang dihubungkan dengan pe- 
rubahan iklim yang terjadi di Teluk Gerupuk Kabupaten Lombok Tengah, Nusa Tenggara Barat. Hasil dari penelitian ini dapat dijadikan data dasar bagi penentuan musim tanam rumput laut, sehingga dapat membantu pembudidaya untuk dapat memaksimalkan produksi berdasarkan musim tanam yang sesuai.

\section{BAHAN DAN METODE}

Penelitian ini dilakukan di Teluk Gerupuk Kabupaten Lombok Tengah Provinsi Nusa Tenggara Barat. Secara geografis, Teluk Gerupuk terletak di pantai Selatan Pulau Lombok yang berhadapan langsung dengan Samudera Hindia (Gambar 1). Luas perairan teluk sekitar 814 ha. Karakteristik perairan di dalam teluk yang cukup terlindung dan relatif dangkal menjadikan perairan ini sangat berpotensi untuk pengembangan budidaya rumput laut.

Data yang dikumpulkan dalam penelitian ini meliputi data primer dan sekunder. Data primer berupa keragaan budidaya rumput laut dan pola musim tanam telah dikumpulkan pada bulan Okto ber 2012. Data ini diperoleh dengan metode survai cepat melalui wawancara dengan responden dan pengisian kuisi- oner. Responden ditentukan berdasarkan pemilihan secara sengaja (purposive sampling; Tangco, 2007) terhadap kelompok aktif yang melakukan budidaya rumput laut di Teluk Gerupuk.

Data sekunder yang dikumpulkan dalam penelitian ini meliputi: (1) Data musim tanam rumput laut tahun 2007-2011; (2) Data iklim (suhu udara, kecepatan angin, dan curah hujan) yang diperoleh dari Badan Meteorologi Klimatologi dan Geofisika (BMKG) stasiun pengamatan Selaparang (data tahun 20052007) dan stasiun pengamatan Bandara Internasional Lombok, Lombok Tengah (data tahun 2008- 2012); (3) Data nilai indeks yang menunjukkan kejadian El Niño dan La Niña (Oceanic Niño Index/ONI) yang diperoleh dari NOAA Climate Prediction Center website (http:/ / www.cpc.ncep.noaa.gov/ products/ analysis_monitoring/ensostuff/ ensoyears. shtml); dan (4) Laporan dan masterplan pengembangan wilayah dari Dinas Kelautan dan Perikanan.

Data yang dikumpulkan kemudian dianalisis dengan melihat hubungannya dan dibahas secara deskriptif yang disertai dengan gambar.

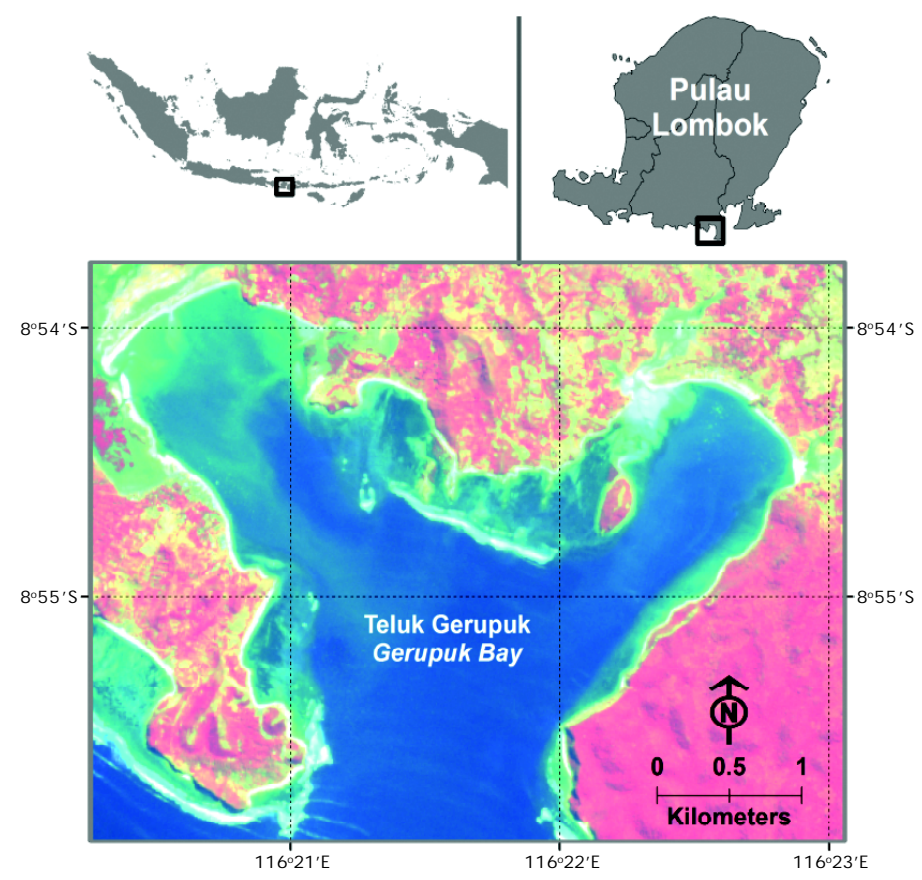

Gambar 1. Lokasi penelitian di Teluk Gerupuk Kabupaten Lombok Tengah, Nusa Tenggara Barat Figure 1. The study area in Gerupuk Bay Central Lombok Regency, West Nusa Tenggara 


\section{HASIL DAN BAHASAN}

\section{Pengembangan Rumput Laut di Lombok Tengah}

Melalui program PIJAR, Provinsi Nusa Tenggara Barat telah menetapkan tiga komoditas unggulan yaitu: sapi, jagung, dan rumput laut (Anonim, 2011a). Program ini diharapkan sebagai terobosan untuk dapat mempercepat penanggulangan kemiskinan, memperkuat ketahanan pangan sekaligus mendorong ketersediaan bahan baku untuk tumbuh dan berkembangnya industri olahan. Implementasi program PIJAR khususnya untuk komoditas rumput laut telah disesuaikan dengan program nasional dari Kementerian Kelautan dan Perikanan (KKP) yaitu minapolitan dan industrialisasi. Sesuai dengan Keputusan Menteri Kelautan dan Perikanan No.: KEP.39/ MEN/ 2011 telah menetapkan lima kabupaten di Provinsi Nusa Tenggara Barat sebagai kawasan minapolitan perikanan budidaya khususnya untuk pengembangan komoditas rumput laut yaitu: Lombok Barat, Lombok Tengah, Sumbawa Barat, Sumbawa, dan Bima.

Untuk mendukung program PIJAR dan KKP, Kabupaten Lombok Tengah berdasarkan Surat Keputusan Bupati Lombok Tengah Nomor 1 Tahun 2011 tanggal 3 Januari 2011 dan Surat Keputusan Bupati Nomor 417 Tahun 2011 tanggal 27 Oktober 2011 tentang pembentukan kelompok kerja minapolitan Kabupaten Lombok Tengah, telah menetapkan kawasan minapolitan di Gerupuk dan Awang sebagai sektor unggulan perikanan dan industri (Anonim, 2011b). Kedua kawasan tersebut memiliki total luasan mencapai 475 ha, di mana pada tahun 2011 tingkat pemanfaatan lahannya baru mencapai 424,63 ha (Anonim, 2011a). Saat ini kegiatan pengembangan budidaya rumput laut telah berjalan di kedua kawasan prioritas tersebut. Rumput laut yang banyak dibudidayakan adalah jenis Kappaphycus alvarezii. Rumput laut jenis ini banyak dikembangkan karena pertumbuhannya cepat, lahan pengembangannya yang memenuhi syarat masih luas, mempunyai potensi pasar yang besar, teknologinya sangat sederhana, dan dapat menyerap tenaga kerja.

Teluk Gerupuk merupakan kawasan potensial pengembangan rumput laut di Kabupaten Lombok Tengah. Dengan luasan teluk yang tidak terlalu besar (834 ha), teluk ini telah dimanfaatkan untuk berbagai aktivitas di antaranya perikanan budidaya (ikan, lobster, dan rumput laut), perikanan tangkap, dan pariwisata (surfing). Hasil analisis pemanfaatan lahan menunjukkan bahwa luasan kawasan teluk yang dapat dimanfaatkan untuk budidaya rumput laut mencapai 322 ha (Radiarta \& Rasidi, 2012). Produksi rumput laut dari kawasan ini menunjukkan fluktuasi yang cukup nyata (Gambar 2). Pada tahun 2009, produksi rumput laut kering mencapai 13.300 ton. Produksi tersebut terus mengalami penurunan tahun 2010 dan 2011 yaitu 10.228,51 ton dan $8.266,99$ ton (Anonim, 2011a). Fluktuasi pro-

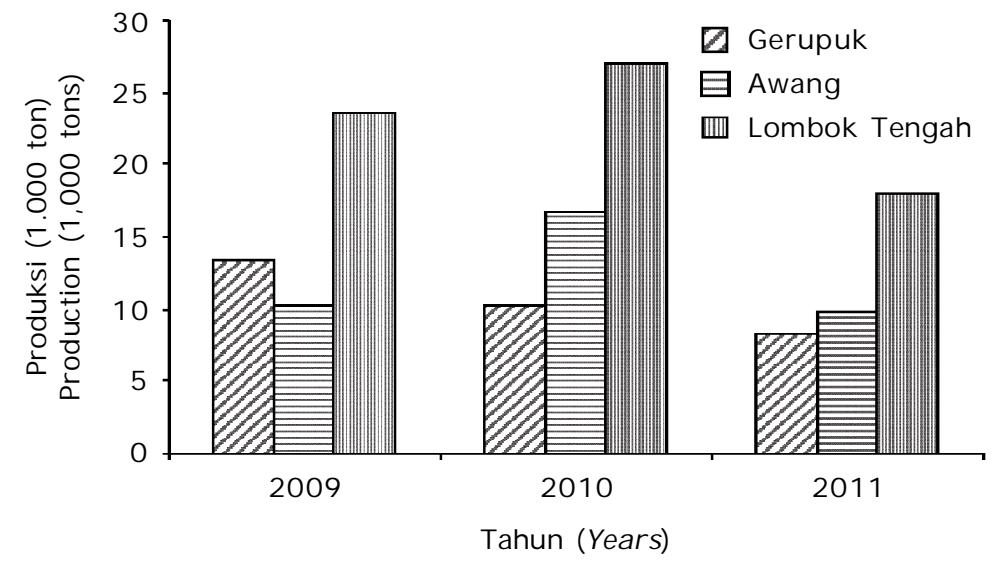

Gambar 2. Produksi rumput laut tahun 2009- 2011 di kawasan minapolitan Gerupuk, Awang, dan Kabupaten Lombok Tengah

Figure2. Seaweed production from 2009-2011 in minapolitan area of Gerupuk, Awang, and Central Lombok Regency 
duksi tersebut dapat disebabkan karena berbagai hal di antaranya kondisi lingkungan perairan dan iklim yang sangat memengaruhi pola musim tanam rumput laut (Pong- Masak et al., 2009; Parenrengi et al., 2011; Rusman, 2012). Kondisi ini secara otomatis akan memengaruhi produktivitas lahan untuk mendukung hasil yang maksimal.

\section{Keragaan Budidaya Rumput Laut}

Potensi pengembangan budidaya rumput laut di Kabupaten Lombok Tengah mencapai 1.200 ha yang tersebar di empat kecamatan yaitu: Kecamatan Pujut, Praya Barat, Praya Barat Daya, dan Praya Timur (Anonim, 2011a) Dari keempat kecamatan tersebut, potensi terbesar dimiliki oleh Kecamatan Pujut, yang meliputi wilayah Teluk Gerupuk. Jenis rumput laut yang dibudidayakan di Teluk Gerupuk adalah jenis K. alvarezii. Sesuai dengan karakteristik lahan yang tersedia, pembudidaya di kawasan menggunakan metode rawai (long line) sebagai media budidaya dengan ukuran satu unitnya adalah $50 \mathrm{~m} \times 50 \mathrm{~m}$. Tabel 1 menyajikan keragaan budidaya rumput laut di Teluk Gerupuk.

Dari keragaan budidaya rumput laut yang berkembang di Teluk Gerupuk umumnya telah sesuai dengan protokol (petunjuk teknis) budidaya rumput laut (Parenrengi et al., 2011 Anonim, 2012b; Pong- Masak et al., 2012), di antaranya: umur bibit yang digunakan sekitar 25- 30 hari, jarak antar titik berkisar antara 15-
$25 \mathrm{~cm}$, dan jarak antar tali ris sekitar 1-2 m. Budidaya rumput laut di Teluk Gerupuk berkembang dengan baik karena didukung oleh kondisi lingkungan perairan yang sesuai (Radiarta \& Rasidi, 2012), ketersediaan sarana budidaya, dan ketersediaan bibit sepanjang tahun. Di lokasi ini, bibit umumnya diperoleh dari hasil budidaya sendiri dengan mengembangkan kawasan kebun bibit. Bibit yang dihasilkan dari lokasi ini selain digunakan sendiri juga dipasarkan ke lokasi lainnya (Pulau Lombok dan Sumbawa). Dengan berkembangnya usaha budidaya rumput laut di lokasi ini, para pembudidaya telah bergabung dalam kelompok pembudidaya. Adanya lembaga teknis berupa Instalasi Balai Budidaya Laut Lombok, di Gerupuk Kecamatan Pujut yang secara langsung ikut membina baik secara teknis maupun non- teknis kepada kelompok pembudidaya di kawasan ini. Dukungan teknis dilakukan melalui pelatihan kepada kelompok pembudidaya untuk dapat mensosialisasikan protokol budidaya rumput laut yang baik dan benar, sehingga diharapkan dapat memaksimalkan produksi yang dicapai. Sedangkan dukungan non-teknis berupa sosialisasi informasi tentang pola/ kalendar musim tanam yang berlaku di kawasan pengembangan.

\section{Kondisi Iklim}

Menurut Kartono et al. (2008), pertumbuhan biomassa rumput laut dipengaruhi antara lain oleh faktor iklim dan lingkungan perairan, di antaranya intensitas cahaya, suhu,

Tabel 1. Keragaan budidaya rumput laut di Teluk Gerupuk, Lombok Tengah Table 1. Seaweed aquaculture variability in Gerupuk Bay, Central Lombok

\begin{tabular}{lcc}
\hline \multicolumn{1}{c}{$\begin{array}{c}\text { Peubah } \\
\text { Parameter }\end{array}$} & $\begin{array}{c}\text { Satuan } \\
\text { Units }\end{array}$ & $\begin{array}{c}\text { Rawai } \\
\text { Long line }\end{array}$ \\
\hline Asal bibit & - & $\begin{array}{c}\text { Kebun bibit } \\
\text { Seed garden }\end{array}$ \\
Seed sources & hari & $25-30$ \\
Umur bibit (Seed age) & $\mathrm{g}$ & $90-500$ \\
Bobot bibit per titik (Weight of seed) & $\mathrm{cm}$ & $15-25$ \\
Jarak antar titik (Distance between points) & $\mathrm{m}$ & $1-2$ \\
Jarak antar tali ris (Distance between rope) & $\mathrm{cm}$ & $0-15$ \\
Kedalaman tali ris dari pemukaan & & \\
Depth of rope from the surface & $\mathrm{m}$ & $15-20$ \\
Kedalaman lokasi budidaya & $\mathrm{m}$ & $400-500$ \\
Water depth in aquaculture area & & \\
Jarak lokasi ke pantai (Distance to the beach) & $\mathrm{m}$ & \\
\hline
\end{tabular}


salinitas, dan gerak air. Pengaruh faktor iklim terhadap lingkungan perairan sangat erat kaitannya (Blenckner, 2005; Radiarta et al., 2011). Oleh karena itu, data iklim (klimatologi) perlu diperhatikan sejalan dengan kondisi lingkungan perairan di lokasi penelitian. Keperluan akan pentingnya data iklim (klimatologi dan meteorologi) juga telah dibahas secara komprehensif oleh Kapetsky (2000) terutama untuk aplikasinya bagi pengembangan budidaya ikan air tawar.

Data klimatologi yang dikumpulkan selama delapan tahun (2005-2012) menunjukkan fluktuasi suhu udara, curah hujan, dan kecepatan angin yang cukup berbeda di setiap tahunnya (Gambar 3). Suhu udara selama tahun 2005-
2012 menunjukkan tren yang relatif sama tiap tahunnya. Namun ada indikasi penurunan suhu pada tahun 2012, terutama pada bulan Juli- Agustus (Gambar 3a). Suhu terendah terjadi pada bulan Juli 2012, sedangkan suhu tertinggi terjadi pada Bulan Desember 2006. Kecenderungan terjadinya penurunan suhu udara (suhu udara minimum) terjadi sekitar bulan Juni- Agustus setiap tahun pengamatan.

Curah hujan selama periode 2005- 2012 dapat dilihat pada Gambar 3b. Jika diperhatikan curah hujan selama periode tersebut terjadi fluktuasi yang sangat berbeda tiap tahunnya. Pada akhir tahun 2010 dapat diketahui curah hujan tertinggi dibandingkan dengan tahun sebelum atau sesudahnya. Dari

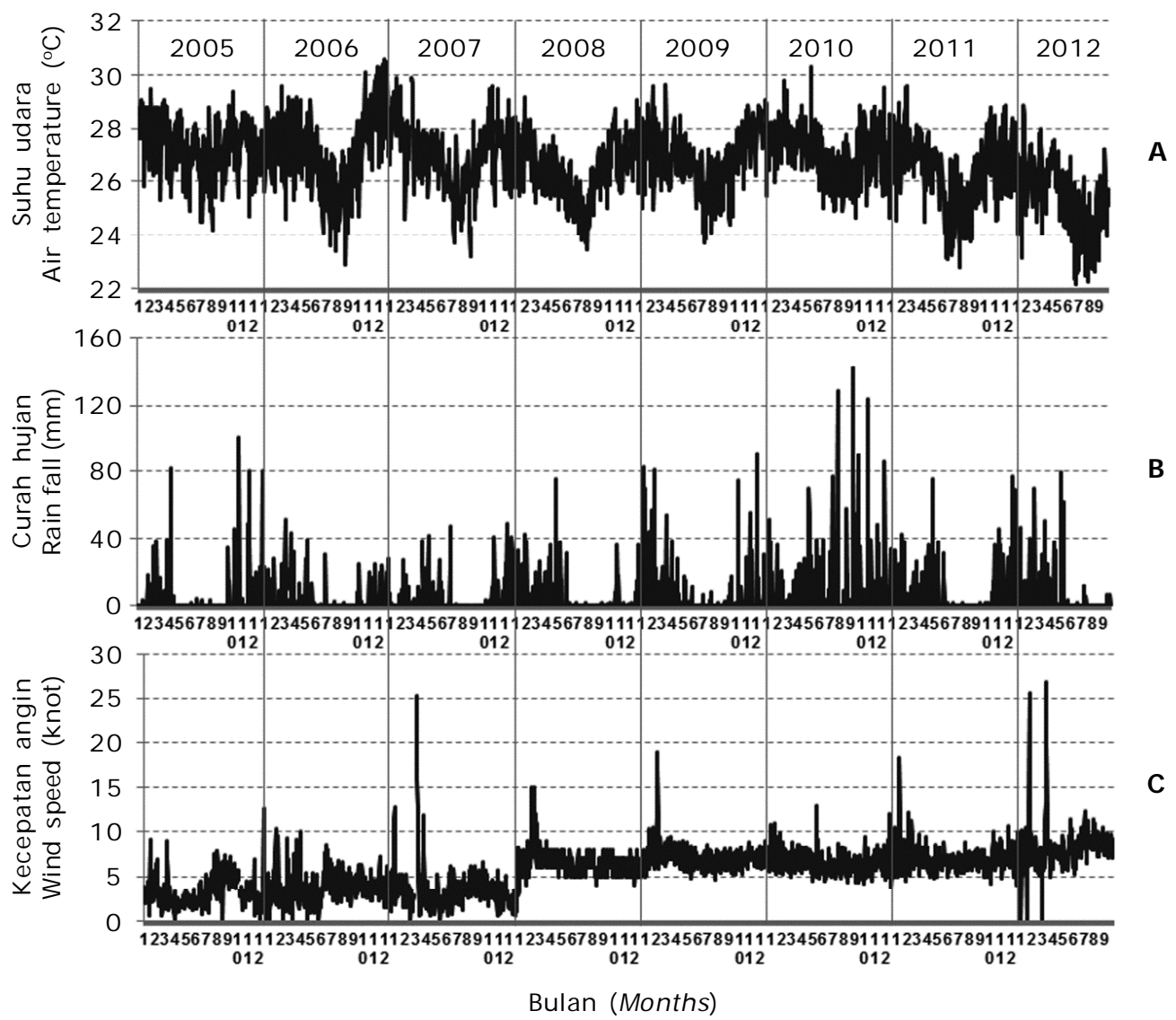

Gambar 3. Data bulanan klimatologi hasil pemantauan dari stasiun BMKG Selaparang dan Bandara Internasional Lombok tahun 2005- 2012: (a) suhu udara, (b) curah hujan, dan (c) kecepatan angin

Figure 3. Monthly climatologi data obtained from Selaparang and Lombok International Airport stations in 2005-2012: (a) air temperature $\left({ }^{\circ} \mathrm{C}\right)$, (b) rain fall (mm), and (c) wind speed (knot) 
delapan tahun pengamatan, curah hujan yang tinggi umumnya terjadi pada bulan NovemberMaret. Sedangkan curah hujan yang rendah terjadi sekitar bulan Juni- Okto ber setiap tahunnya kecuali tahun 2010 (Gambar 3b). Pada saat curah hujan minimum, suhu udara umumnya menunjukkan nilai terendah (Gambar 3a, 3b). Kondisi ini sangat mendukung bagi aktivitas budidaya rumput laut yang berkembang di Teluk Gerupuk. Rendahnya suhu udara tentunya akan berkorelasi terhadap rendahnya suhu permukaan perairan. Suhu perairan yang ideal untuk budidaya rumput laut adalah berkisar antara $28^{\circ} \mathrm{C}-30^{\circ} \mathrm{C}$ (Tiensongrusmee, 1990; Mubaraket al., 1990). Sedangkan rendahnya curah hujan akan berpengaruh terhadap kestabilan salinitas perairan dan meminimalkan terjadinya serangan penyakit terhadap rumput laut.

Data kecepatan angin menjadi penting karena dapat memengaruhi kondisi gelombang perairan di lokasi penelitian. Teluk Gerupuk yang posisinya menghadap langsung ke Samudera Hindia, sangat dipengaruhi oleh kondisi gelombang perairan. Kondisi gelombang ini tentunya akan sangat memengaruhi aktivitas budidaya rumput laut terutama terhadap media budidaya yang dioperasikan. Kecepatan angin maksimal umumnya terjadi pada awal tahun sekitar bulan Februari- April (Gambar 3c). Dalam kurun waktu delapan tahun (2005-2012), kecepatan angin maksimum terjadi pada awal tahun 2012. Pada bulan di mana kecepatan angin maksimum umumnya pembudidaya rumput laut tidak melakukan usaha budidaya secara maksimal, namun hanya bersifat mempertahankan bibit yang berlokasi di kawasan yang cukup terlindung. Dengan memperhatikan fluktuasi tiga parameter klimatologi ini, sangat memengaruhi pola/ kalendar musim tanam yang berlaku di Teluk Gerupuk.

\section{Kondisi Iklim Global (EI Niño dan La Niña)}

Untuk melihat perubahan iklim yang terjadi, para ahli telah melakukan berbagai cara untuk mengkarakterisasi perubahan yang terjadi baik regional maupun global. Kondisi iklim secara global di perairan Indonesia umumnya dikaitkan dengan fenomena El Niño dan La Niña. El Niño dan La Niña merupakan suatu kejadian perubahan iklim dunia yang tidak lazim jika dibandingkan dengan iklim normal yang terjadi dalam kurun waktu ter- tentu, yaitu suatu keadaan iklim berubah atau menyimpang dalam jangka waktu pendek yang disebabkan oleh adanya gejala alam yang tidak normal dengan ditandai oleh naiknya suhu permukaan air laut di atas rata- rata (Thatje et al., 2008). Kejadian El Niño berhubungan erat dengan tingkat kekeringan atau kurangnya curah hujan yang terjadi. Sedangkan La Niña berhubungan dengan tingginya curah hujan yang terjadi.

Satu pendekatan yang umum digunakan untuk melihat anomali iklim adalah melalui zona indeks. Oceanic Niño Index (ONI) merupakan satu zona indeks yang sangat populer di wilayah Pasifik tropis, yang dapat berdampak pada perubahan lingkungan perairan dan daratan. Pendekatan menggunakan zona indeks ini secara umum sangat bermanfaat untuk melihat dampak perubahan iklim terhadap perubahan lingkungan. Hal ini disebabkan indeks ini mengintegrasikan berbagai variabel iklim (misalnya suhu, curah hujan, dan tutupan awan) dan memungkinkan melihat variasinya secara tahunan untuk iklim regional. Berdasarkan ONI tahun 1995- 2012 menunjukkan bahwa fenomena El Niño yang paling ekstrim terjadi pada tahun 1997-1998, dengan nilai ONI lebih dari 2 (Gambar 4; http:/ / www.cpc. ncep.noaa.gov/products/analysis. monitoring/ ensostuff/ensoyears.shtml). Indikasi adanya fenomena El Niño dan La Niña ditunjukkan dari nilai ONI. Jika Nilai ONI melebihi 0,5 berarti terjadi El Niño, dan sebaliknya jika nilai ONI lebih kecil dari - 0,5 berarti terjadi La Niña (ditunjukkan dengan garis putus- putus pada Gambar 4). Dalam bidang perikanan, dampak dari El Niño dan La Niña ini sudah sangat dirasakan terutama berhubungan dengan tingkat kesuburan perairan (Susanto \& Marra, 2005) dan pola migrasi ikan (Anda- Montañez et al., 2004). Untuk perikanan budidaya, Baba et al. (2009) melakukan kajian pada budidaya scallop dan menemukan bahwa terjadinya El Niño dapat memengaruhi rendahnya kelimpahan spat yang tersedia, sedangkan La Niña menunjukkan pengaruh yang sangat signifikan terhadap reproduksi dan pertumbuhan dari scallop.

Kondisi iklim global ini sangat berhubungan erat dengan kondisi iklim lokal di Indonesia. Dari Gambar 3 dan 4 dapat dilihat bahwa kejadian La Niña dengan kategori medium pada tahun 2010- 2011 berimplikasi pada tingginya curah hujan yang terjadi di Kabupaten Lombok Tengah. Kondisi El Niño (kering/kemarau) dan 


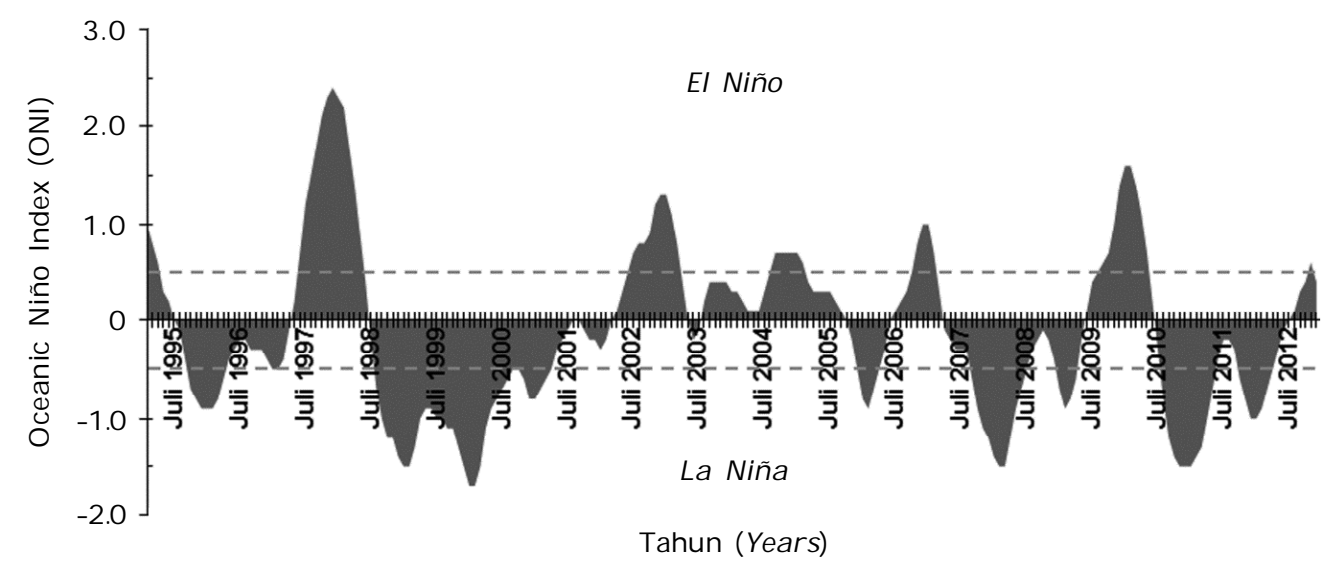

Gambar 4. Oceanic Niño Index (ONI) dari tahun 1995- 2012 yang digunakan sebagai indikasi fenomena El Niño dan La Niña

Figure 4. Oceanic Niño Index (ONI) from 1995-2012 that commonly used as indication for El Niño and La Niña events

La Niña (curah hujan tinggi) menjadi perhatian tersendiri pada saat penyusunan kalendar musim tanam budidaya rumput laut (PongMasak et al., 2009; Rusman, 2012). Kedua fenomena ini secara nyata telah memengaruhi dan menurunkan produktivitas lahan budidaya rumput laut.

\section{Pola Musim Tanam Rumput Laut}

Pola (kalendar) musim tanam rumput laut dapat dipengaruhi oleh kondisi lingkungan perairan dan kondisi iklim (klimatologi dan meteorologi). Kondisi iklim yang paling diperhatikan dalam penyusunan kalendar musim tanam rumput laut adalah musim panas dan penghujan. Intensitas curah hujan yang sangat tinggi akan memengaruhi kondisi salinitas perairan berupa turunnya nilai salinitas yang sesuai untuk budidaya rumput laut. Rumput laut jenis K. alvarezii merupakan rumput laut yang tidak tahan terhadap kisaran salinitas yang lebar. Salinitas yang sesuai untuk pertumbuhannya adalah 28-35 ppt, namun pertumbuhan optimal dicapai pada salinitas 32- 35 ppt (Sudradjat, 2009; Parenrengi et al., 2011). Menurut Dawes (1976), perubahan salinitas yang lebih rendah berpengaruh terhadap proses osmoregulasi pada rumput laut. Pada saat salinitas perairan rendah terjadi proses penyerapan air oleh rumput laut lebih banyak, akibatnya kondisi rumput laut menjadi rapuh dan secara perlahan akan rontok. Kondisi seperti ini sering terjadi pada waktu musim penghujan. Rendahnya salinitas perairan (kurang dari 20 ppt) juga dapat memicu terjadinya peyakit ice-ice. Sebaliknya musim panas yang berkepanjangan yang mengakibatkan suhu air laut meningkat mencapai sekitar $33^{\circ} \mathrm{C}-35^{\circ} \mathrm{C}$ yang disertai dengan kondisi arus dan kecerahan yang kurang mendukung dapat juga menyebabkan timbulnya penyakit ice-ice atu dikenal juga dengan nama white spot (Pong- Masak et al., 2009; Parenrengi et al., 2011). Penyakit ini merupakan kendala utama yang dapat menyebabkan kegagalan panen budidaya rumput laut. Ice-ice merupakan penyakit dengan tingkat infeksi cukup tinggi di negara Asia penghasil Eucheuma (Santosa \& Nugraha, 2008).

Hasil penelitian menunjukkan musim tanam rumput laut jenis K. alvarezii di Teluk Gerupuk cukup berfluktuatif pada kurun waktu enam tahun terakhir (Tabel 2). Pada tahun 2007 musim tanam yang produktif mulai bulan AprilOktober. Sedangkan musim tanam yang kurang produktif di bulan Januari, November, dan Desember. Tahun 2008 musim tanam yang produktif mulai bulan Juni- Oktober. Sedangkan musim tanam yang kurang produktif pada bulan Januari- April dan Desember. Pola musim tanam yang terjadi tahun 2007 dan 2008 menunjukkan bulan musim produktif yang serupa, namun di tahun 2008 bulan produktif relatif lebih singkat dibandingkan dengan tahun 2007. Serangan penyakit (ice-ice dan lumut) di tahun 2007 umumnya dijumpai pada bulan Januari- Maret, Mei- Juni, dan November- 
Tabel 2. Musim tanam rumput laut di Teluk Grupuk Kabupaten Lombok Tengah Table2. Planting period for seaweed in Gerupuk Bay Central Lombok Regency

\begin{tabular}{|c|c|c|c|c|c|c|c|c|c|c|c|c|c|}
\hline \multirow{2}{*}{$\begin{array}{l}\text { Musim tanam } \\
\text { Planting periods }\end{array}$} & \multirow{2}{*}{$\begin{array}{l}\text { Tahun } \\
\text { Years }\end{array}$} & \multicolumn{12}{|c|}{ Bulan (Months) } \\
\hline & & 1 & 2 & 3 & 4 & 5 & 6 & 7 & 8 & 9 & 10 & 11 & 12 \\
\hline \multirow{6}{*}{$\begin{array}{l}\text { Musim produktif } \\
\text { Productive periods }\end{array}$} & 2007 & & & & & & & & & & & & \\
\hline & 2008 & & & & & & & & & & & & \\
\hline & 2009 & & & & & & & & & & & & \\
\hline & 2010 & & & & & & & & & & & & \\
\hline & 2011 & & & & & & & & & & & & \\
\hline & 2012 & & & & & & & & & & & & \\
\hline \multirow{6}{*}{$\begin{array}{l}\text { Musim tidak produktif } \\
\text { Non-productive periods }\end{array}$} & 2007 & & & & & & & & & & & & \\
\hline & 2008 & & & & & & & & & & & & \\
\hline & 2009 & & & & & & & & & & & & \\
\hline & 2010 & & & & & & & & & & & & \\
\hline & 2011 & & & & & & & & & & & & \\
\hline & 2012 & & & & & & & & & & & & \\
\hline \multirow{6}{*}{$\begin{array}{l}\text { Serangan penyakit } \\
\text { Disease periods }\end{array}$} & 2007 & & & & & & & & & & & & \\
\hline & 2008 & & & & & & & & & & & & \\
\hline & 2009 & & & & & & & & & & & & \\
\hline & 2010 & & & & & & & & & & & & \\
\hline & 2011 & & & & & & & & & & & & \\
\hline & 2012 & & & & & & & & & & & & \\
\hline
\end{tabular}

Desember. Kejadian serangan penyakit ini lebih sering terjadi dibandingkan dengan tahun 2008 (Tabel 2).

Pola musim tanam untuk tahun 2009 dan 2010 juga berbeda dengan musim tanam dua tahun sebelumnya. Musim tanam untuk dua tahun ini menunjukkan pola yang serupa. Musim tanam produktif pada tahun 2009 berkisar antara bulan Januari- Februari dan September-Desember, sedangkan tahun 2010 berkisar antara bulan Januari- Februari dan November- Desember. Musim tanam yang kurang produktif pada tahun 2009 dan 2010 terjadi pada kurun waktu yang bersamaan yaitu antara bulan Mei- Agustus. Serangan penyakit terjadi lebih sering pada tahun 2009 dibandingkan dengan tahun 2010 (Tabel 2).

Untuk tahun 2011 dan 2012, memiliki pola musim tanam yang serupa baik itu musim produktif, musim tidak produktif, dan serangan penyakit. Musim tanam produktif untuk tahun 2011 terjadi pada kisaran bulan Juni- Oktober, sedangkan tahun 2012 berkisar antara bulan
Mei- Oktober. Tahun 2011, serangan penyakit lebih sering ditemui dibandingkan dengan tahun 2012 (Tabel 2).

Perubahan musim tanam rumput laut dilihat dari perubahan iklim di antaranya suhu udara, intensitas curah hujan, dan kecepatan angin di Teluk Gerupuk menunjukkan keterkaitan yang jelas (Gambar 3 dan Tabel 2). Musim tanam produktif umumnya terjadi pada bulan di mana curah hujan rendah (musim kemarau) dan suhu udara juga rendah $\left(24^{\circ} \mathrm{C}-27^{\circ} \mathrm{C}\right)$. Pada periode bulan tersebut ditandai juga dengan kondisi kecepatan angin yang minimum. Kondisi klimatologi ini sangat mendukung untuk melakukan penanaman secara maksimal sehingga produksi rumput laut yang dihasilkan dapat maksimal. Sebaliknya musim tidak produktif umumnya terjadi pada saat curah hujan tinggi dan angin kencang sehingga sangat memengaruhi kondisi lingkungan perairan dan kondisi gelombang (Gambar 3). Perubahan kecepatan angin akan memengaruhi perubahan tinggi gelombang air laut terutama 
di Teluk Gerupuk yang berhadapan langsung dengan Samudera Hindia. Seperti terlihat pada tahun 2012, musim tanam produktif terjadi pada kisaran bulan Juni- September di mana pada saat bulan tersebut kondisi curah hujan dan kecepatan angin relatif kecil (Gambar 3 dan Tabel 2). Sebagai pembanding, Rusman (2012) melakukan kajian musim tanam di Perairan Sekotong. Hasil kajian tersebut menunjukkan bahwa musim produktif terjadi pada bulan Juni- November. Sedangkan serangan penyakit (ice-ice) terjadi pada bulan Maret- Juni. Pada saat musim penghujan bulan November- Maret umumnya rumput laut tidak berproduksi. Pada saat bulan tersebut, pembudidaya hanya mempertahankan rumput laut sebagai bibit.

Berdasarkan data klimatologi dan pola musim tanam yang ada di Teluk Gerupuk menunjukkan dengan jelas adanya dampak perubahan iklim terhadap musim tanam yang berlaku. Pemantauan selama enam tahun menunjukkan bahwa pola musim tanam ini tidak sama setiap tahunnya tergantung pada karakteristik iklim yang dapat memengaruhi kondisi perairan setempat. Secara umum perubahan pola musim tanam ini dapat memengaruhi tingkat produktivitas Iahan pengembangan (Gambar 2). Penerapan pola musim tanam yang baik akan menjadi bagian dari pemeliharaan lingkungan perairan, di mana pada saat musim pertumbuhan rumput laut yang tidak menguntungkan maka sebaiknya pembudidaya rumput laut berhenti untuk menanam sehingga lingkungan dapat kembali pulih seperti keadaan semula. Hal ini dilakukan selain dapat meminimalkan kegagalan panen karena iklim dan kejadian penyakit (Pratiwi \& Ismail, 2004), juga berfungsi untuk menjaga tingkat kesuburan perairan.

\section{Perspektif Pengembangan Kedepan}

Pemanfaatan data iklim (klimatologi dan meteorologi) untuk menduga secara cepat pola/ kalendar musim tanam rumput laut merupakan suatu langkah strategis yang dapat ditempuh guna dapat meningkatkan produktivitas lahan, serta meminimalkan terjadinya kegagalan panen yang dapat disebabkan karena kondisi iklim dan lingkungan yang tidak mendukung. Penyusunan pola musim tanam rumput laut umumnya memperhatikan beberapa masalah atau parameter meliputi: musim puncak (produktif), musim rusak, musim survival, serangan ice-ice, serangan epifit dan lumut, musim hujan, dan musim kemarau. Untuk memperoleh semua data dan informasi tersebut harus dilakukan kajian yang sangat detail sehingga masalah dan parameter tersebut dapat diidentifikasi dengan jelas. Untuk memberikan gambaran umum tentang pola musim tanam rumput laut, data iklim dapat dimanfaatkan. Melalui data iklim tersebut, musim produktif dapat diidentifikasi dengan mudah berdasarkan musim kemarau dan musim penghujan. Contoh aplikasi pola musim tanam dengan memanfaatkan data iklim/ cuaca terkini adalah dalam bidang pertanian (Hidayati \& Chrisendo, 2010; Widayati, 2012). Kalender tanam untuk padi ini telah pula disosialisasikan melalui website: www.katam.litbang.deptan. go.id, sehingga masyarakat umum dapat mengakses data dan informasi yang tersedia. Dengan adanya kalender musim tanam ini, pemerintah dapat mengumumkan kalendar tanam dua bulan sebelum masa tanam, baik masa tanam musim hujan maupun musim kemarau.

Dengan melihat sistem yang telah dibentuk oleh pertanian, bukan suatu hal yang tidak mungkin, ke depan pola musim tanam rumput laut yang disusun berdasarkan kondisi iklim/ cuaca terkini juga dapat disusun baik spesifik lokasi suatu kawasan, regional, dan nasional. Untuk dapat membentuk sistem tersebut, tentunya harus didukung dengan penelitian di beberapa lokasi pengembangan rumput laut di Indonesia dan kerja sama antar instansi di antaranya Badan Meteorologi Klimatologi dan Geofisika (BMKG) dan Balai Penelitian Observasi Laut (BPOL), Badan Penelitian dan Pengembangan Kelautan dan Perikanan. Peran BMKG adalah menyediakan kondisi iklim secara real time, sedangkan BPOL dapat menyediakan data karakteristik kondisi perairan laut baik melalui data lapangan maupun pendekatan citra satelit. Melalui kerja sama tersebut diharapkan data yang tersedia dapat dimanfaatkan untuk menyusun pola musim tanam yang akurat.

\section{KESIMPULAN}

Kondisi perubahan iklim sangat memengaruhi produktivitas Iahan, di antaranya Iahan pengembangan budidaya rumput laut di Teluk Gerupuk, Lombok Tengah. Hasil yang diperoleh dari penelitian ini dapat disimpulkan bahwa: Produktivitas lahan pengembangan rumput laut sangat dipengaruhi oleh kondisi iklim. Adanya perubahan iklim baik nasional 
maupun global (El Niño dan La Niña) sangat memengaruhi pola musim tanam rumput laut di Teluk Gerupuk. Musim tanam produktif umumnya terjadi pada bulan di mana curah hujan rendah (musim kemarau) dan suhu udara juga rendah $\left(24^{\circ} \mathrm{C}-27^{\circ} \mathrm{C}\right)$.

Belajar dari sistem kalender musim tanam produk pertanian, pola musim tanam rumput laut juga bisa disusun. Dukungan penelitian dan kerja sama antar instansi perlu dilakukan guna mencapai tujuan tersebut.

\section{UCAPAN TERIMA KASIH}

Penulis mengucapkan terima kasih kepada Idil Ardi dan Rasidi, tim survai pemanasan global Pusat Penelitian dan Pengembangan Perikanan Budidaya yang telah membantu kelancaran pengumpulan data. Penelitian in merupakan bagian dari penelitian "dampak pemanasan global terhadap perikanan budidaya" Pusat Penelitian dan Pengembangan Perikanan Budidaya T.A. 2012.

\section{DAFTARACUAN}

Anda- Montañez, J.A.D., Amador- Buenrostro, A Martines- Anguilar, S., \& Muhlia- Almazan, A. 2004. Spatial analysis of yellowfin tuna (Thunus albacares) catch rate and its relation to El Niño and La Niña events in the eastern tropical Pacific. Deep-Sea Research II, 51: 575- 586.

Anonim. 2011a. Pijar. Evaluasi kegiatan program 2011 \& rencana kinerja tahun 2012. Pemerintah Provinsi Nusa Tenggara Barat, $71 \mathrm{hlm}$.

Anonim. 2011b. Rencana induk pengembangan kawasan minapolitan Kabupaten Lombok Tengah. Pemerintah Kabupaten Lombok Tengah. Dinas Kelautan dan Perikanan, 144 hlm.

Anonim. 2012a. Blue economy: Pembangunan kelautan dan perikanan berkelanjutan untuk kesejahteraan masyarakat (sustainability-social inclusiveness-innovative investment). Kementerian Kelautan dan Perikanan, $32 \mathrm{hlm}$.

Anonim. 2012b. Petunjuk teknis budidaya rumput laut. Balai Budidaya Laut Lombok, Direktorat Jenderal Perikanan Budidaya, Kementerian Kelautan dan Perikanan, Jakarta, $31 \mathrm{hlm}$.

Baba, K., Sugawara, R., Nitta, H., Endou, K., \& Miyazono, A. 2009. Relationship between spat density, food availability, and growth of spawners in cultured Mizuhopecten yessoensis in Funka Bay: concurrence with ENSO. Canadian Journal of Fisheries and Aquactic Sciences, 12: 6- 17.

Blenckner, T. 2005. A conceptual model of climate- related effects on lake ecosystems. Hydr obioilogia, 533: 1- 14.

Dawes, C.J. 1976. Marine Botany. University of South Florida, $628 \mathrm{pp}$.

FAO Fisheries and Aquaculture Department. 2012. Global aquaculture production (online query). http:// www.fao.org/figis/ servlet/TabSelector, diunduh tanggal 28 Desember 2012.

Hidayati, R. \& Chrisendo, D.N. 2010. Prediction of planting date and growing period using sea surface temperature (SST) anomalies in NINO 3.4 for Indramayu District. J. Agromet., 24(2): 1-8. Available online at: http:// journal.ipb.ac.id/index.php/ agromet.

Kapetsky, J.M., 2000. Present applications and future needs of meteorology and climatology data in inland fisheries and aquaculture. Agricultural and Forest Meteorology, 103: 109- 117.

Kartono, Izzati, M., Sutimin, \& Insani, D. 2008. Analisis model dinamik pertumbuhan biomassa rumput laut Gracillaria verrucosa. Jurnal Matematika, 11(1): 20- 24.

Mubarak, H., Ilyas, S., Ismail, W., Wahyuni, I.S., Hartati, S.H., Pratiwi, E., Jangkaru, Z., \& Arifuddin, R. 1990. Petunjuk teknis budidaya rumput laut. Badan Litbang Pertanian, Puslitbang Perikanan. IDRC, Infish. $93 \mathrm{hlm}$.

Parenrengi, A., Rachmansyah, \& Suryati, E. 2011. Budidaya rumput laut penghasil karaginan (Karaginofit). Balai Riset Perikanan Budidaya Air Payau, Badan Penelitian dan Pengembangan Kelautan dan Perikanan, Kementerian Kelautan dan Perikanan, Jakarta, $54 \mathrm{hlm}$.

Pratiwi, E. \& Ismail, W. 2004. Perkembangan budidaya rumput laut di Pulau Pari. Warta Penelitian Perikanan Indonesia, 10(2): 1115.

Pong- Masak, P.R., Tjaronge, M., \& Madeali, M.I. 2009. Musim tanam rumput laut di perairan Tonra Kabupaten Bone, pantai Timur Sulawesi Selatan. Prosiding Forum Inovasi Teknologi Akuakultur 2009. Pusat Riset Perikanan Budidaya, Badan Riset Kelautan dan Perikanan, Jakarta, hlm. 413-421.

Pong Masak, P.R., Parenrengi, A., Tjaronge, M., \& Rusman. 2012. Protokol seleksi varietas 
bibit unggul rumput laut. Balai Penelitian dan Pengembangan Budidaya Air Payau, Pusat Penelitian dan Pengembangan Perikanan Budidaya, Badan Penelitian dan Pengembangan Kelautan dan Perikanan, Kementerian Kelautan dan Perikanan, Jakarta, $27 \mathrm{hlm}$.

Radiarta, I N. \& Rasidi. 2012. Analisa spasial kondisi kualitas perairan untuk mendukung budidaya rumput laut di Teluk Gerupuk Kabupaten Lombok Tengah Provinsi Nusa Tenggara Barat. Prosiding Seminar Nasional Perikanan Indonesia 2012. Sekolah Tinggi Perikanan Jakarta. (inpress).

Radiarta, I N., Saputra, A., \& Albasri, H. 2012. Pemetaan kelayakan lahan budidaya rumput laut (Kappaphycus alvarezii) di Kabupaten Bintan Provinsi Kepulauan Riau dengan pendekatan sistem informasi geografis dan penginderaan jauh. J. Ris. Akuakultur, 7(1): 145- 147.

Radiarta, I N., Kristanto, A. H., \& Saputra, A. 2011. Kondisi meteorologi, klimatologi, dan perikanan di kawasan Waduk Cirata, Jawa Barat: Analisis awal kemungkinan dampak pemanasan global terhadap perikanan budidaya. J. Ris. Akuakultur, 6(3): 495- 506.

Rusman. 2012. Kesesuaian musim tanam rumput laut jenis kotoni (Kappaphycus alvarezii) di Perairan Sekotong, Lombok Barat, Nusa Tenggara Barat. Laporan hasil penelitian (tidak dipublikasi). $14 \mathrm{hlm}$.
Santosa, L. \& Nugraha, Y.T. 2008. Pengendalian penyakit ice-ice untuk meningkatkan produksi rumput laut Indonesia. Jurnal Saintek Perikanan, 3(2): 37- 43.

Sudradjat, A. 2009. Budidaya 23 komoditas laut menguntungkan. Cetakan ke 2. Penebar Swadaya. Jakarta, $172 \mathrm{hlm}$.

Susanto, R.D. \& Marra, J. 2005. Effect of the 1997/ 1998 El Nino on chlorophyll a variability along the southern coasts of Java and Sumatra. Oceanography, 18(4): 124127.

Tangco, A.D.C. 2007. Purposive sampling as a tool for informant selection. Ethnobotany Research \& Applications, 5:147- 158.

Thatje, S., Heilmayer, O., \& Laudien, J. 2008. Climate variability and El Nino Southtern Oscillation: implication for natural coastal resources and management. Helgol. Mar. Res., 62 (suppl. 1): S5- S14.

Tiensongrusmee, B. 1990. Site selection for Eucheuma spp. farming. UNDP/FAO Regional Seafarming Development and Demonstration Project (RAS/ 90/002). Kasetsart University Campus, Bangkok, Thailand. http:// www.fao.org/ docrep/ field/003/ AB738E/ AB738E00.htm\#TOC disadur tanggal 30 November 2010.

Widayati, S. 2012. Kalender tanam berbasis informasi cuaca terkini. Majalah Sain Indonesia. PT Sarana Komunikasi Utama, edisi 7 Juli 2012, hlm. 38- 39. 